\title{
BMI SANDWICH WING BOX ANALYSIS AND TEST
}

\author{
Tod Palm - Mary Mahler - Chandu Shah . \\ Northrop Grumman Corporation \\ Marshall Rouse $\bullet$ Harold Bush $\bullet$ Chauncey Wu $\bullet$ William J. Small \\ NASA Langley Research Center
}

\section{ABSTRACT}

A composite sandwich single bay wing box test article was developed by Northrop Grumman and tested recently at NASA Langley Research Center. The objectives for the wing box development effort were to provide a demonstration article for manufacturing scale up of structural concepts related to a high speed transport wing, and to validate the structural performance of the design. The box concept consisted of highly loaded composite sandwich wing skins, with moderately loaded composite sandwich spars. The dimensions of the box were chosen to represent a single
\end{abstract}

bay of the main wing box, with a spar spacing of 30 inches, height of 20 inches constant depth, and length of 64 inches. The bismaleimide facesheet laminates and titanium honeycomb core chosen for this task are high temperature materials able to sustain a $300^{\circ} \mathrm{F}$ service temperature. The completed test article is shown in Figure 1. The tests at NASA Langley demonstrated the structures ability to sustain axial tension and compression loads in excess of $20,000 \mathrm{lb} / \mathrm{in}$, and to maintain integrity in the thermal environment. Test procedures, analysis failure predictions, and test results are presented.

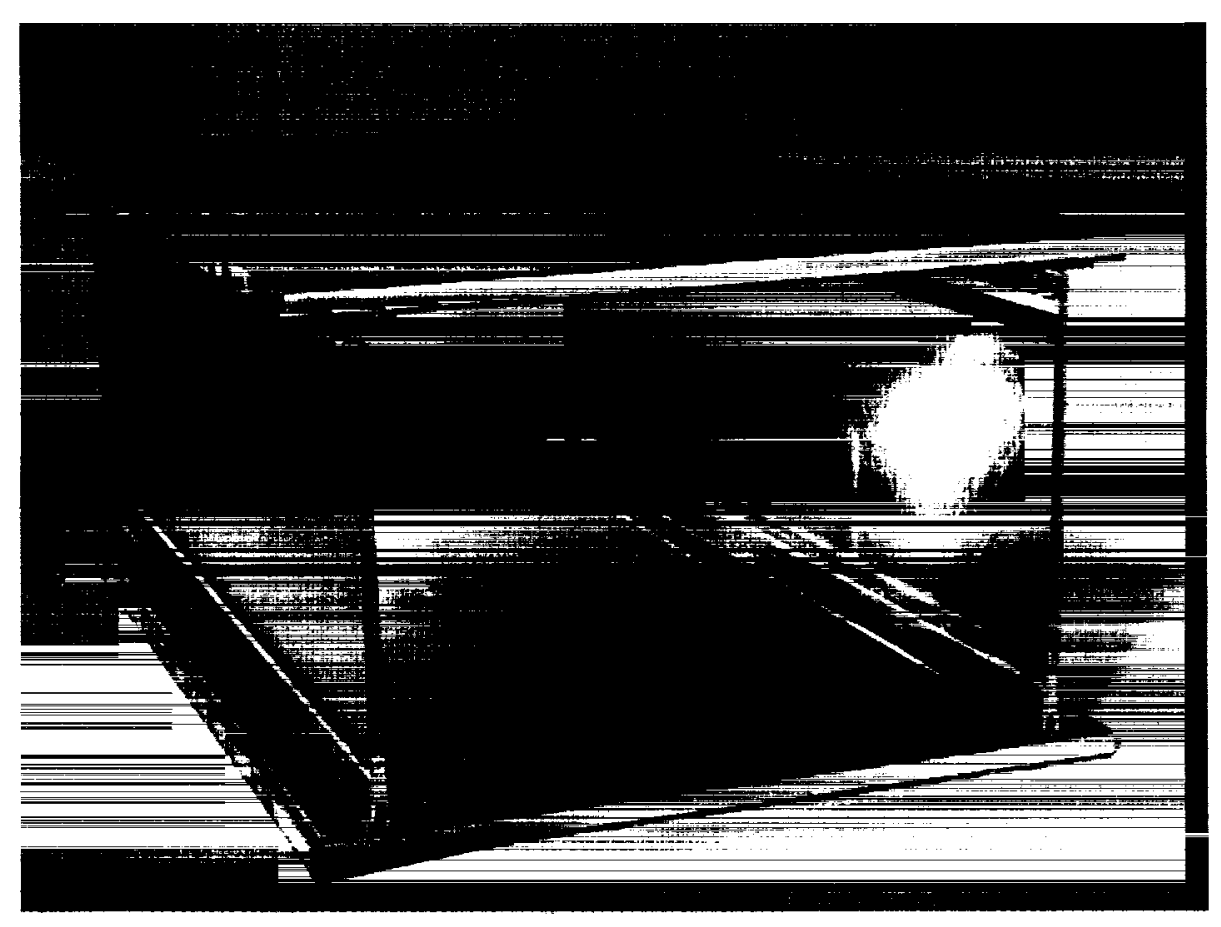

Figure 1. Composite Sandwich Single Bay Wing Box Test Component

Copyright (C) 2000 by Tod Palm. Published by the American Institute of Aeronautics and Astronautics, Inc., with permission. 


\section{BACKGROUND}

Wing box design and fabrication (Reference 1) were performed under NASA contract NAS1-18842. The sandwich skin panels consist of IM7/5260 toughened BMI facesheets over titanium honeycomb core. The 1.0 inch thick core material is 8.0 pound-per-cubic-foot hexagonal core with a $3 / 16$ inch cell size, 0.002 inch wall thickness, and spot welded nodes. The skin panel facesheets were sized based on notched compressive strain allowable of 4,600 micro-strain for the IM7/5260 material. The facesheet thickness distribution varies from 20 plies at the tip $\left(50 \% 0^{\circ}\right.$ plies) to 28 plies at the root $\left(64 \% 0^{\circ}\right.$ plies). Local facesheet doubler laminates were incorporated in the splice regions to increase laminate bearing strength.

The sandwich spar webs also consist of IM7/5260 toughened BMI facesheets over titanium honeycomb core. The 0.50 inch thick core material is 6.0 pound-percubic-foot square cell core with a $3 / 16$ inch cell size, .002 inch wall thickness, and laser welded nodes. The facesheets are 12 plies $( \pm 45 / 0 / \pm 45 / 90)$ s laminates. The core ramps down at an angle of $27^{\circ}$ to close out the core at the top of the spar, and provides a solid laminate region for attachment to the T cap. A 12 ply, 0.0624 inch thick doubler laminate was placed between the facesheets for enhanced laminate bearing strength in the bolted spar cap region.

A bonded composite H-section configuration was chosen for attachment of the spars to the lower wing skin, while a bolted composite T-joint was selected for the upper attachment. The bonded joint was preferred on the lower surface to reduce fuel penetrations in the skin. The bolted joint was chosen over a bonded design for the upper attachment to avoid bonding together a closed section. A fully bonded construction raised issues of inspectability and producibility for a large commercial transport, and was therefore dropped as a design option. Both the bonded and bolted joint selections were supported by element test data from work performed by Northrop Grumman under NAS119347, Tasks 5 and 6.

The wing design loads were based on the ultimate loads for a subsonic $3.75 \mathrm{~g}$ pull-up maneuver at maximum gross takeoff weight. The axial skin loads selected for the wing box component were $10 \mathrm{kips} / \mathrm{in}$ at the tip and $20 \mathrm{kips} / \mathrm{in}$ at the root. The average shear loads in the spar webs for the same load condition were $2.5 \mathrm{kips} / \mathrm{in}$.

\section{LOADS AND TEST PLAN}

The skin splices between the wing skins and the load introduction structure were a critical design concern due to the applied load of $20,000 \mathrm{lb} / \mathrm{in}$. A three row bolted joint was designed, with a solid block of titanium replacing the core in the splice region and protruding from the end of the test box. The metal load introduction boxes reacted loads into outer splice plates and the center block, resulting in multiple load paths. Titanium tabs were added to the outer facesheets to further increase the bearing margins.

The test fixture was designed to sustain loads of 20,000 Ibs/in in-plane and 2,500 lbs/in beam shear. The existing backstop at NASA LaRC was considered inadequate to support a cantilevered test of the box, and a selfreacting four point bending fixture was therefore designed for the test. The new wing box test fixture design, shown in Figure 2, was based on load introduction by four-point bending. The design and analysis for the fixture were conducted at the Northrop Grumman. The test fixture fabrication was a joint effort between NGC and NASA team. Details for the test fixture design and wing box test results were documented under NASA contract NAS1-20220 (Reference 2). The applied loads at each cylinder, and corresponding shear and moment diagrams for the wing box subcomponent are shown schematically in Figure 3. The load introduction structure was sized for a margin of safety of 2.0 at ultimate load for the majority of the fixture, with local areas designed to M.S. $=1.5(30,000$ $\mathrm{lb} / \mathrm{in})$ at the skin splice regions.

The test plan included four test conditions. Condition 1 consisted of taking the box to $300^{\circ} \mathrm{F}$ temperature with no applied mechanical loads. In Condition 2 the box was subjected to limit design load (67\% of ultimate mechanical loading) at room temperature. The Condition 3 loading consisted of design limit load with $300^{\circ} \mathrm{F}$ temperature. In Condition 4 , the box was loaded to failure at room temperature. Wing box instrumentation included a total of 115 axial strain gages including shear gages, 18 rosette gages, 72 thermocouples, 4 LVDT, 4 displacement gages (DCDT), 3 ambient temperature monitoring sensors and 8 load measuring instruments were employed for the test. 


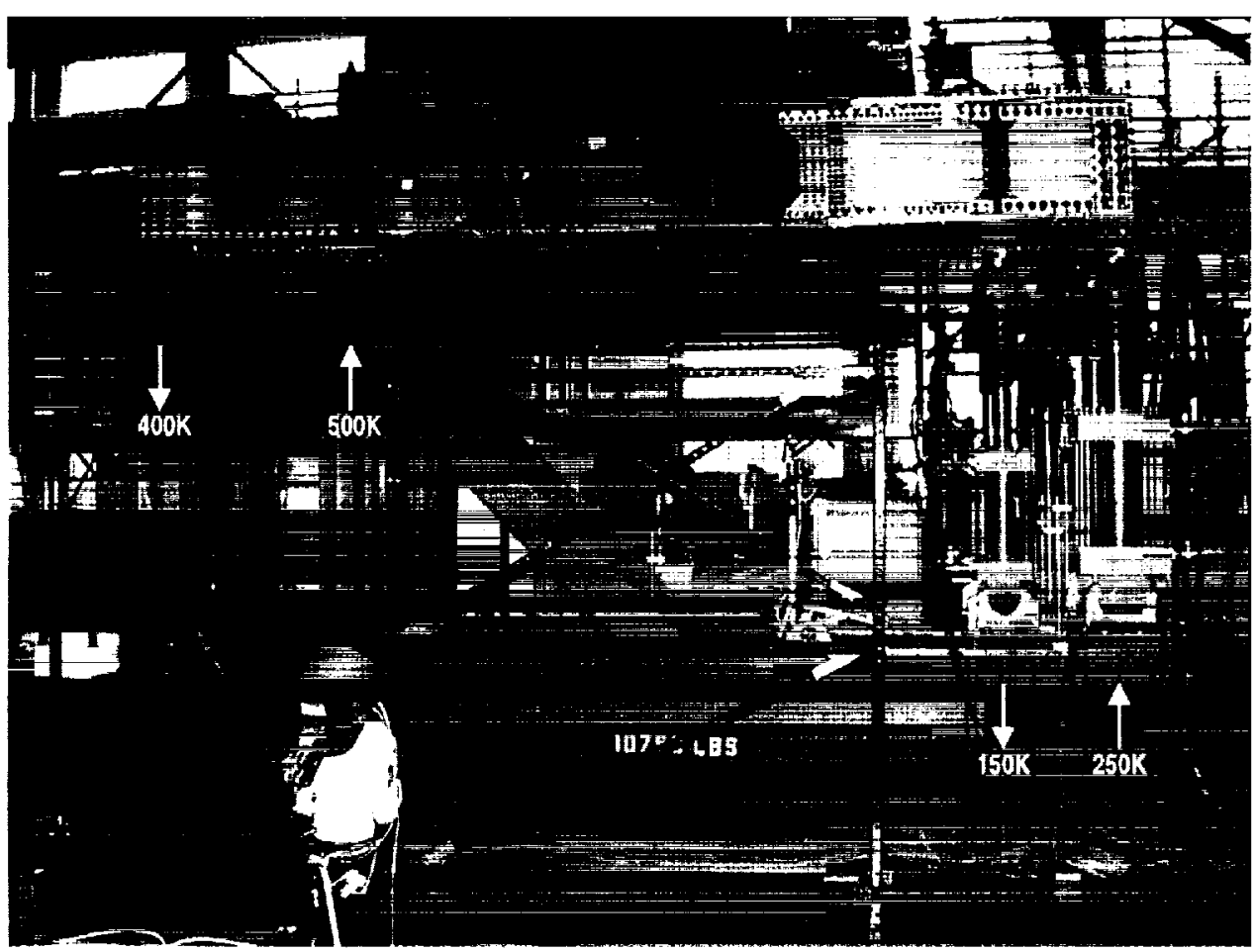

Figure 2. Composite Sandwich Single Bay Wing Box Test Setup at NASA Langley

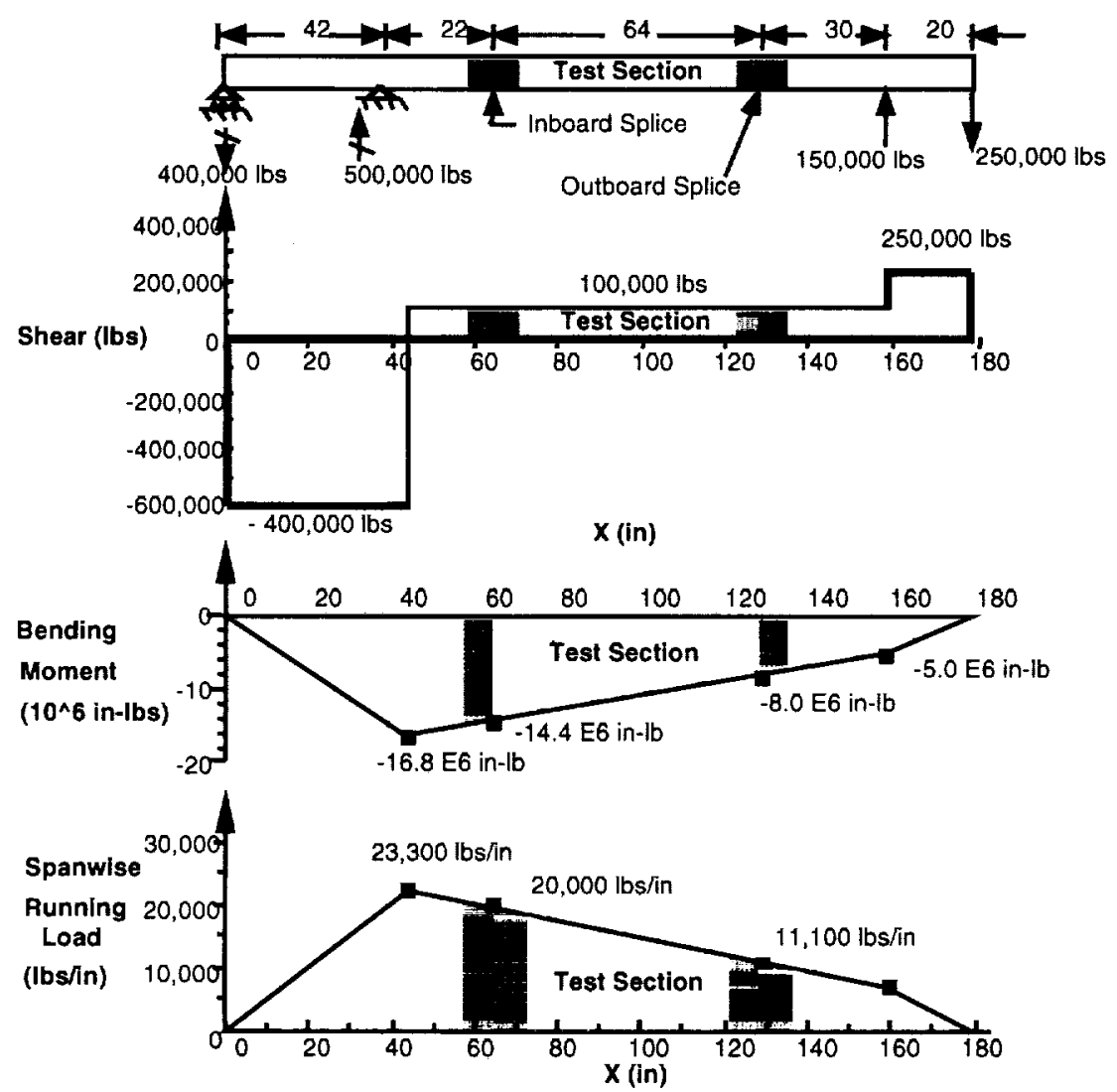

Figure 3. Test Loads and Ultimate Loading of Wing Box Subcomponent 


\section{FINITE ELEMENT ANALYSIS RESULTS}

A NASTRAN finite element model was used to correlate the strain and deflection of the wing box. The wing test box and metal load introduction box assemblies were characterized using a symmetric half model with 1,819 plate elements and 11,205 degrees of freedom. The model, shown in Figure 4, used brick and bar elements at the support locations to simulate the support flexibility of the load reaction fixture. The beam deflection predicted by the NASTRAN model, shown in Figure 5, matched those measured during the test within $8 \%$. The actual deformations for the test article were higher than predicted values due to flexibility of the load introduction bolted splices, which were not included in the model. Deformations within the test section matched predicted values within $5 \%$.

Failure predictions were based upon the notched compressive strain allowable for the IM7/5260 facesheets at 5400 microstrain, which resulted in a zero margin of safety at the bolted spar attachment near the reaction end of the wing box at ultimate load. A summary of the margins of safety for the test article at ultimate load is shown in Figure 6. The measured test strains in the critical region, plotted in Figure 7, reached a maximum value of 5300 microstrain. The final failure occurred at $119 \%$ ultimate load, and initiated in this region.

Analysis correlation for the finite element model predictions versus the actual measured axial strain data are shown in Figures 8 and 9. Figure 8 shows the compressive strain contours at ultimate load for the lower skin panel with the bolted spar cap attachment. The measured strain data at ultimate load are included in boxes linked to the gage locations on the subcomponent. In general, the measured strains correlated within $6 \%$ of the predicted values. Axial strain concentrations were observed in the skins near the spar attachments due to shear lag across the wing box.
The centerline strain values were approximately $20 \%$ less than those predicted near the spars at each end of the test component. The axial strains were uniform across the width of the box near the mid-span of the test article, and measured $\sim 5000 \mu$ at ultimate load.

The tensile load analysis correlation shown in Figure 9 exhibited similar behavior to the lower compressive skin. The highest measured strain of $5680 \mu$ occurred at the reaction end of the box, near the bonded spar web joint, and was $6 \%$ higher than the analysis prediction. There are no local stress concentrations from fasteners in this region because the bonded $\mathrm{H}$-joint incorporates a uniform slot through the inner moldline facesheet to accommodate the pre-cured $\mathrm{H}$-section. The presence of the continuous slot allows the inner and outer facesheets of the tensile skin to operate near the unnotched allowable strain $(\sim 11,000 \mu)$, and the calculated margin of safety for this skin was therefore high.

\section{WING BOX FAILURE MODE}

The failure initiated as a compression failure in the bolted sandwich skin near the reaction side as predicted by the NASTRAN analysis. The failure region is shown in Figure 10. The local compressive failure of the facesheet at the boltline propagated across the lower skin panel, disbonding the severed outer moldline facesheet in the process. As the bolted sandwich skin failed, the box lost its bending capability. This caused the sandwich spar web to fail in shear. The shear failure propagated at 45 degrees across the spar web, until reaching the upper tension sandwich panel. This bonded sandwich skin failed in a local bending mode approximately 20 inches inboard from the load reaction splice. The spar sandwich and bonded sandwich skin were both secondary forms of failure. The remainder of the wing box test article is structurally intact, and no further damage propagation was observed. 


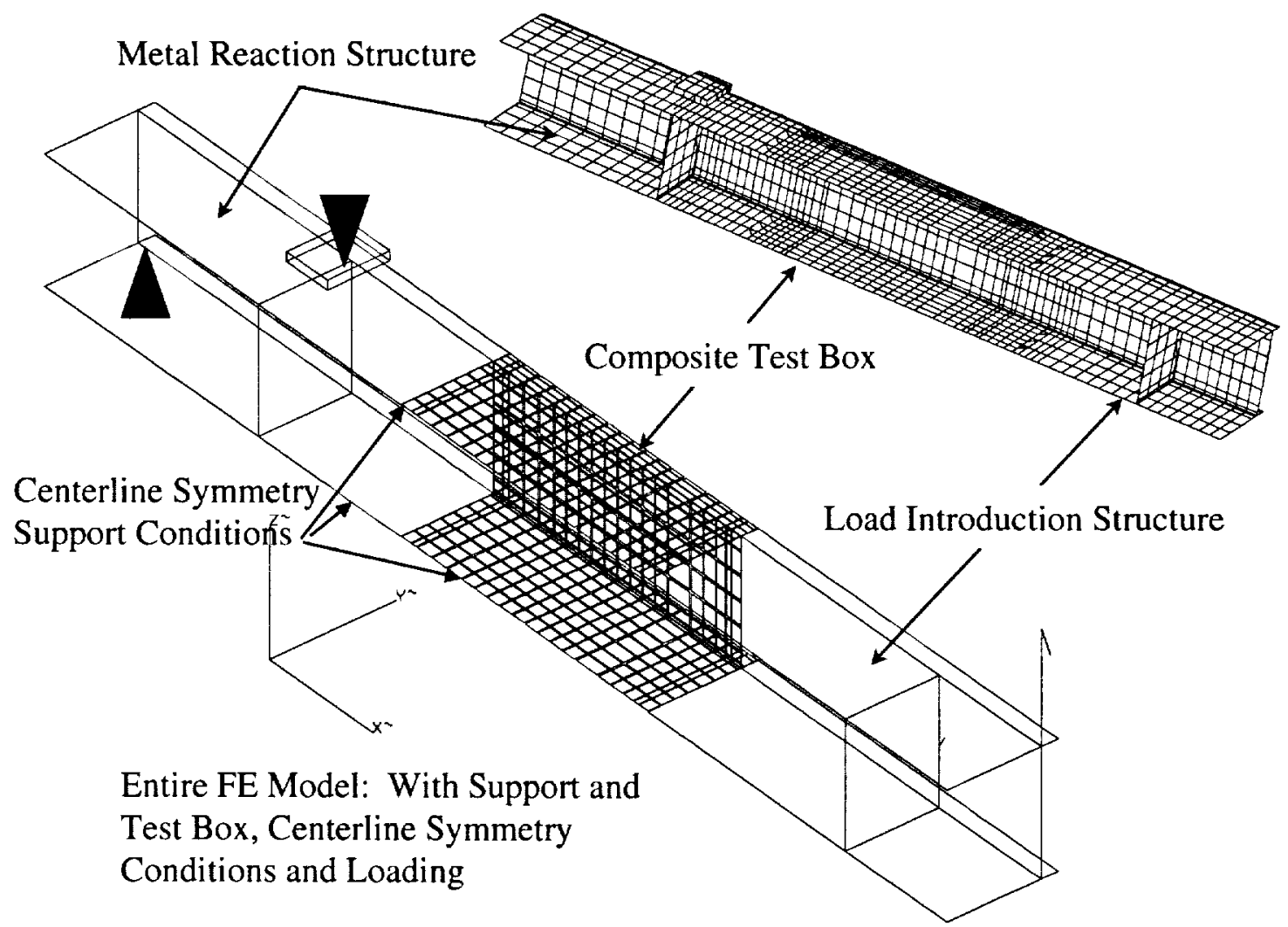

Figure 4. Finite Element Model Used for Mechanical Loading Prediction
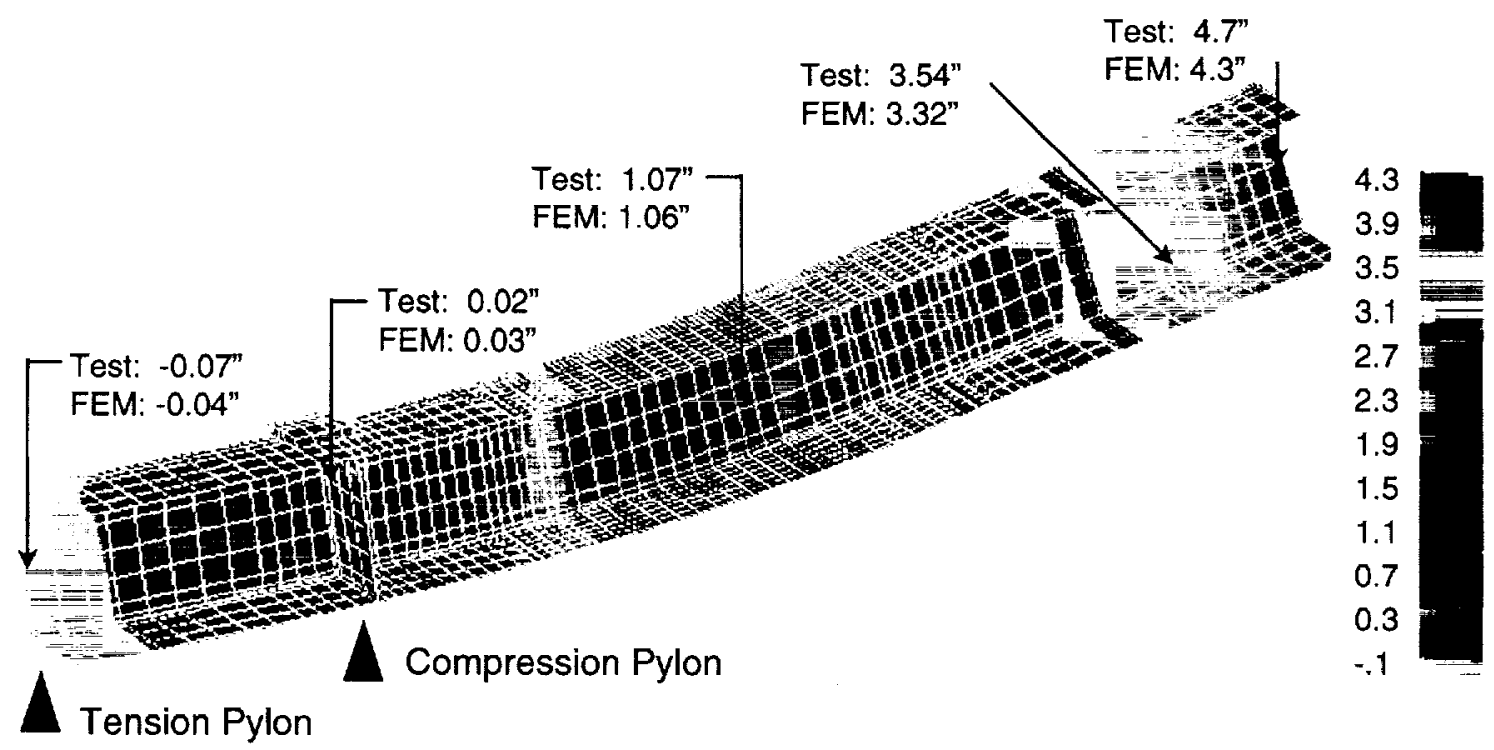

Figure 5. Wing Box Model Deformation Comparison With Test Data 


\begin{tabular}{|c|c|c|c|c|}
\hline Location & $\begin{array}{c}\begin{array}{c}\text { Critical Failure } \\
\text { Mode }\end{array} \\
\end{array}$ & $\begin{array}{c}\text { Design } \\
\text { Allowable } \\
\end{array}$ & $\begin{array}{c}\text { Minimum } \\
\text { Margin } \\
\end{array}$ & $\begin{array}{l}\text { Laminate } \\
\text { Thickness } \\
\end{array}$ \\
\hline Lower Skin & Facesheet Tensile Rupture & $\begin{array}{c}\text { OHT Strain } \\
=7,500 \mu \mathrm{in} / \mathrm{in}\end{array}$ & 0.17 & 28 Plies \\
\hline Upper Skin & Facesheet Compression Failure & $\begin{array}{l}\text { FHC Strain } \\
=5,400 \mu \mathrm{in} / \mathrm{in}\end{array}$ & 0.00 & 28 Plies \\
\hline Spar Web & Facesheet Shear Failure & $\begin{array}{l}\text { FHC Strain } \\
\text { (Transformed) } \\
=5,000 \mu \mathrm{in} / \mathrm{in}\end{array}$ & 0.32 & 12 Plies \\
\hline T- Joint & $\begin{array}{c}\text { Laminate Crushing Due to } \\
\text { Bolt Bending }\end{array}$ & & 0.14 & 36 Plies \\
\hline H-Joint & $\begin{array}{l}\text { Shear Failure of } \\
\text { Inboard Angle }\end{array}$ & & 0.14 & $\begin{array}{l}6 \text { Plies } \\
\text { (woven) } \\
\end{array}$ \\
\hline
\end{tabular}

Figure 6. Summary of Minimum Margins of Safety at Ultimate Load

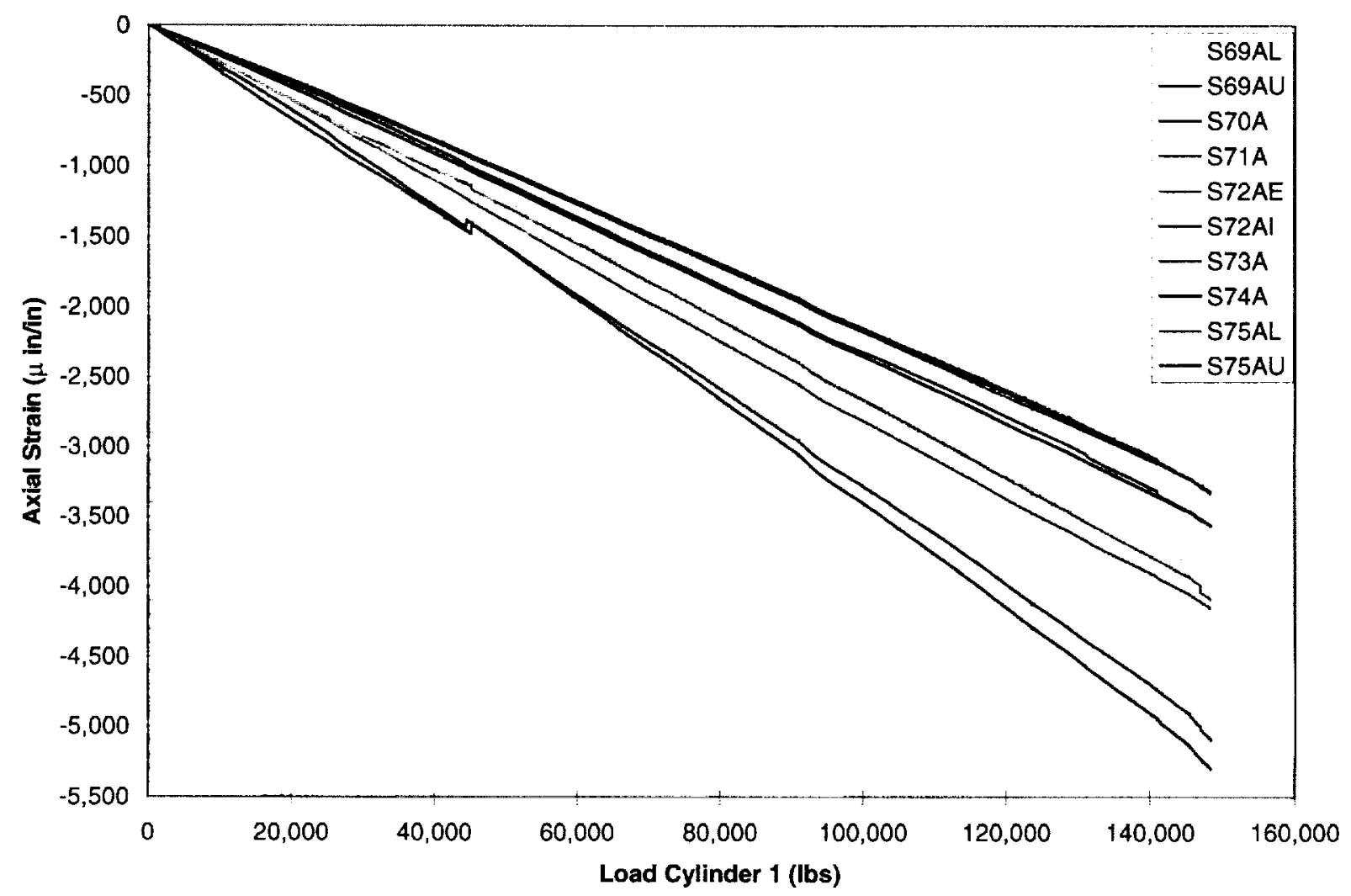

Figure 7. Compressive Strains at Reaction End of Wingbox 


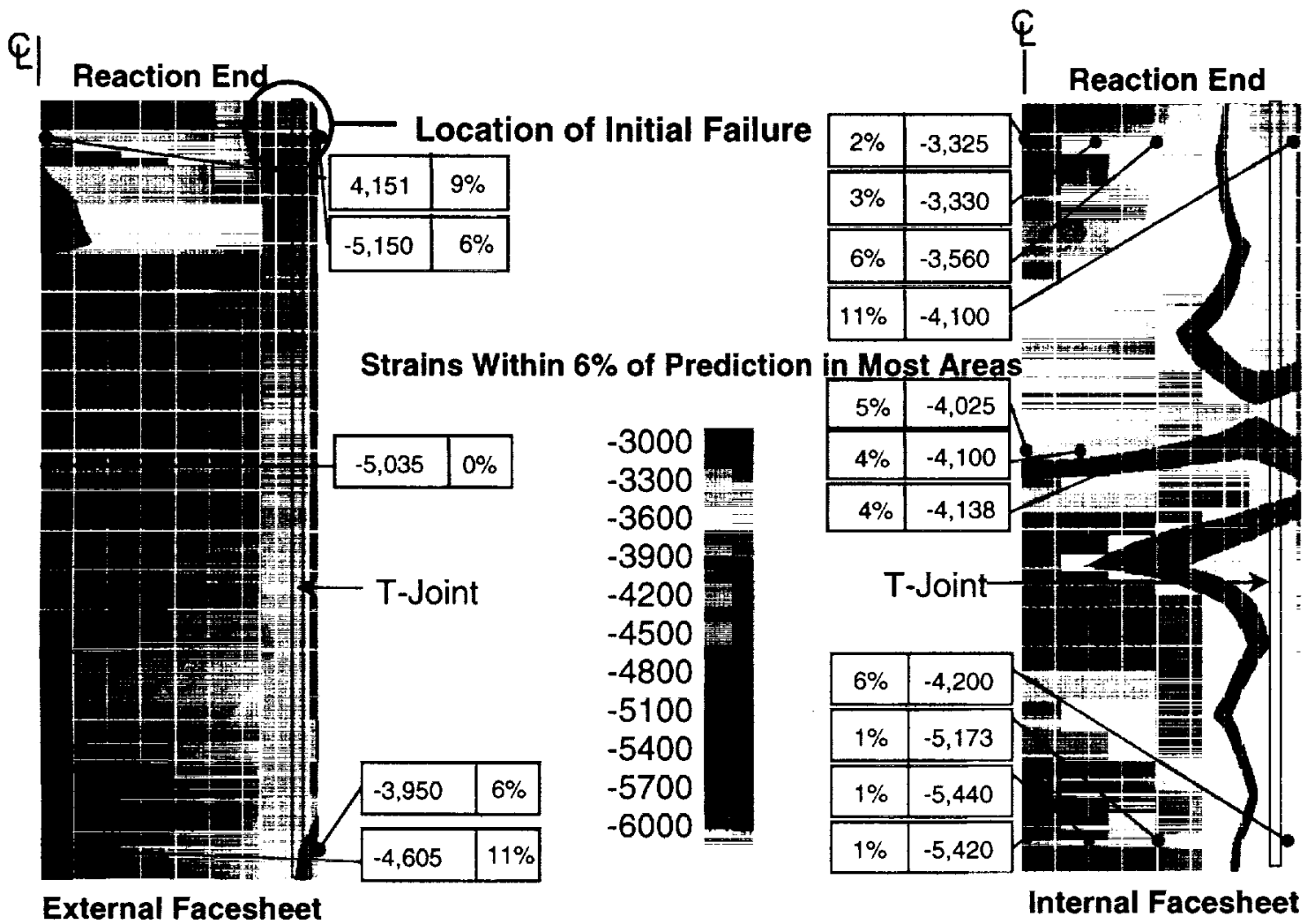

Figure 8. Correlation of Compressive Strains on Lower Skin Panel at Ultimate Load

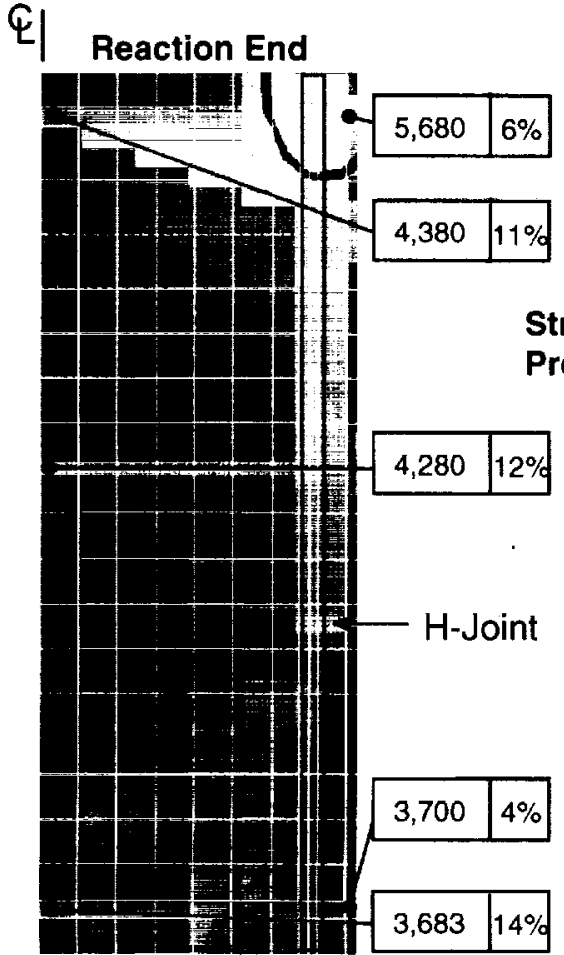

External Facesheet
Strains Within $12 \%$ of Prediction in Most Areas

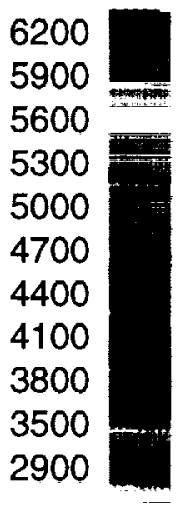

Figure 9. Correlation of Tensile Strains on Upper Skin Panel at Ultimate Load
E| Reaction End

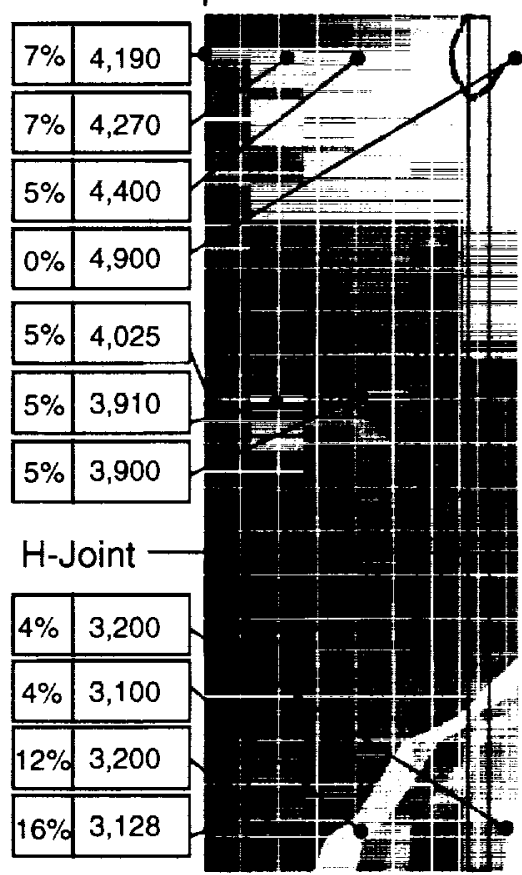

Internal Facesheet 


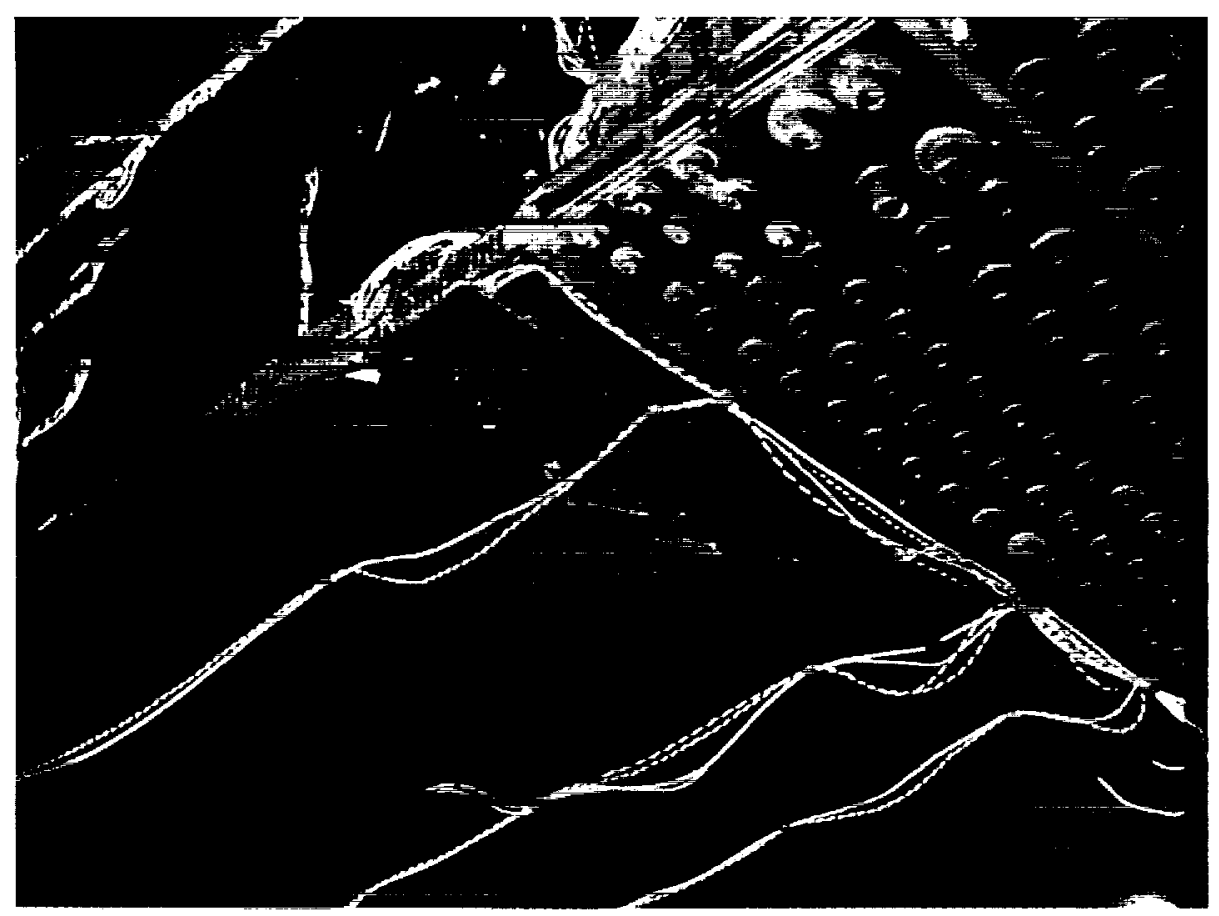

Figure 10. Wing Skin Compression Failure at $119 \%$ Ultimate Load

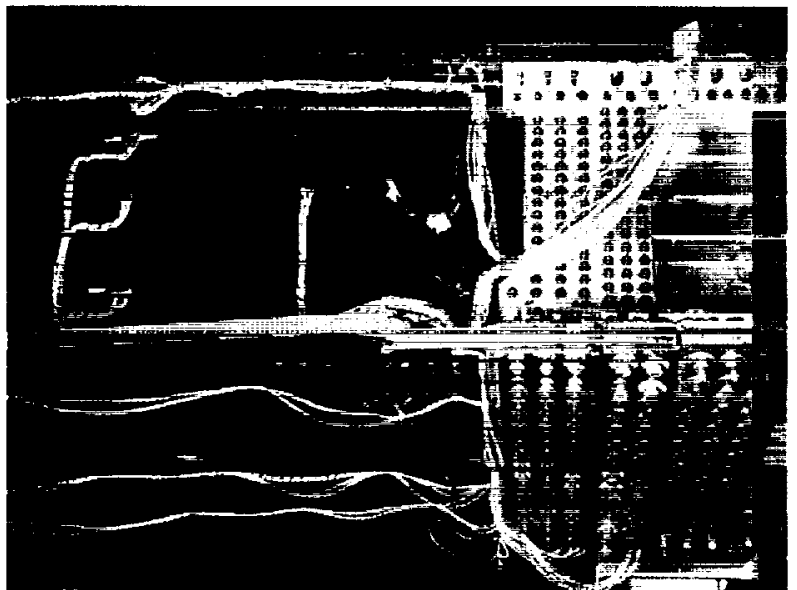

Figure 11. Wing Spar Secondary Shear Failure, Right Side

\section{SUMMARY}

The wing box test program was a complete success, and validated the performance of an all composite sandwich wing box subjected to extreme bending loads typical of those for high speed transport wings. Thermal results also indicated that the selected materials were capable of sustaining flight limit loads in the $300^{\circ} \mathrm{F}$ environment. The failure at $119 \%$ of design ultimate load proved the capability of composite sandwich structures to sustain high magnitudes of structural load,

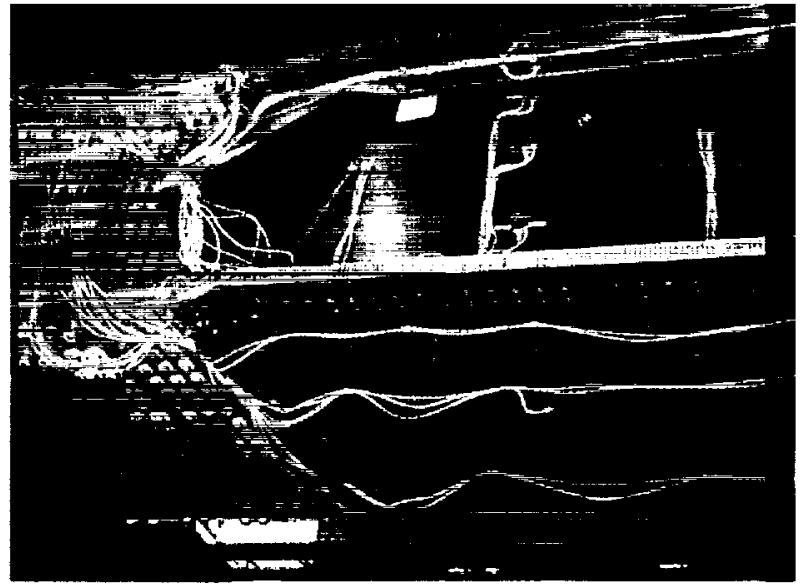

Figure 12. Wing Spar Secondary Shear Failure, Left Side

and the ability to accurately model and predict these loads and failure modes. The close coordination between the NASA and Northrop Grumman participants on the test fixturing produced a system capable of producing the extreme loads required for this test. The high magnitude of load in the wing skins resulted in greater levels of complexity for the load introduction boxes than originally anticipated in meeting the factor of safety requirements for the fixture. In future programs it is highly recommended that conservative estimating practices be used for any fixtures requiring 
over 10,000 lb/in of running load capability. This conclusion was reinforced by other related experience on the HSR program (Reference 3 ).

\section{REFERENCES}

1. Deo, R.B., Russell, S.G., and Palm, T.E., "Innovative Structural Concepts for Supersonic Transports," NASA Contract NAS1-18842 Final Report, March 1997.

2. "BMI Sandwich Single Bay Wing Box Test Bismaleimide Matrix Composite Honeycomb Sandwich Concept," Boeing Subcontract RD-27263C, Deliverable Item 24-10-02, December 1998.

3. "High Speed Research Program, Summary Report for Task 16 Materials and Structures Damage Tolerance and Task 25 Fuselage Structures," 30 September 1999. 


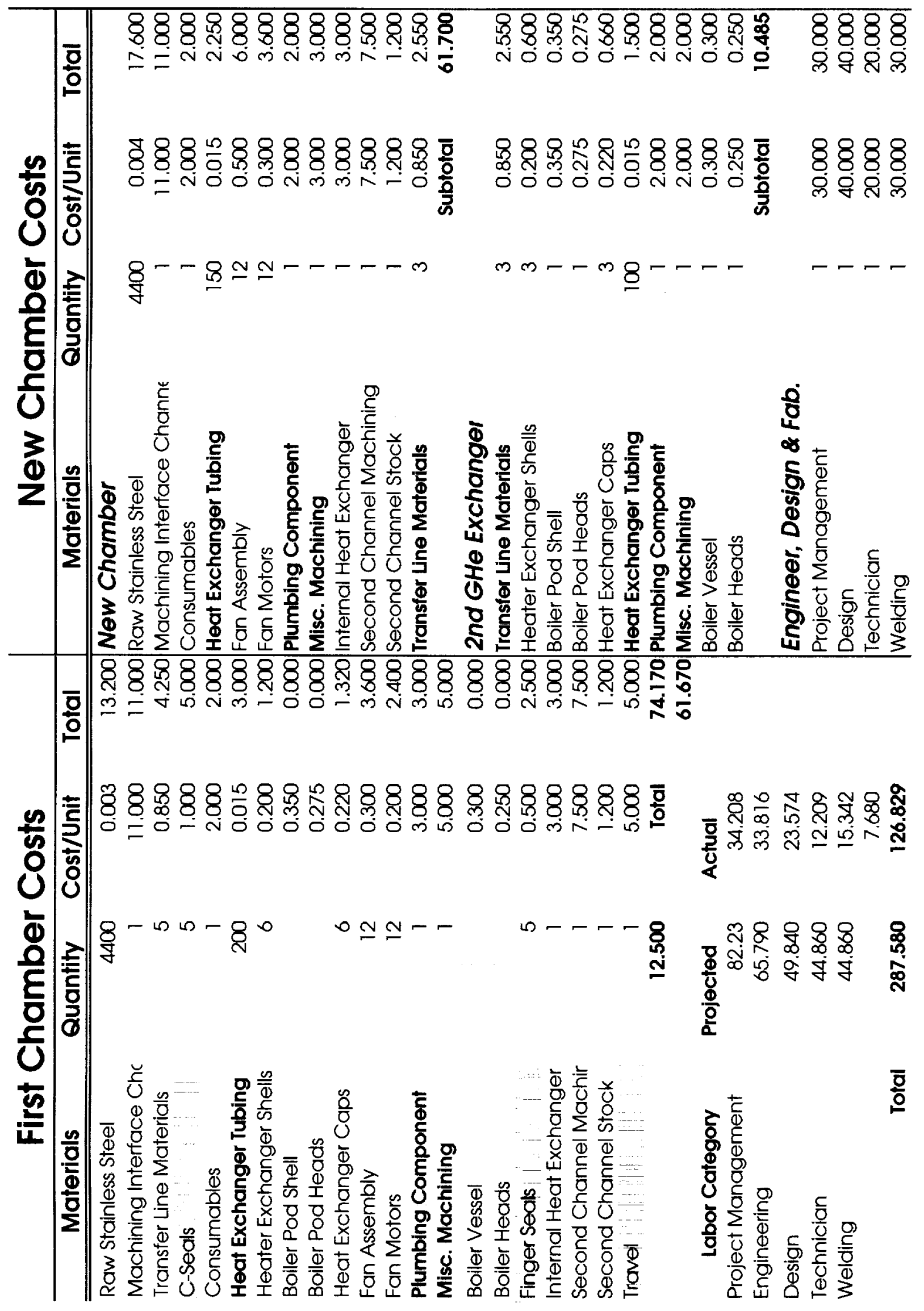




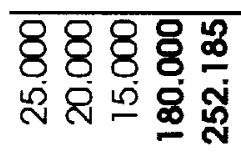

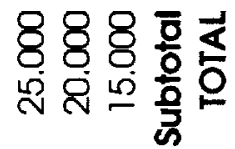

- - -

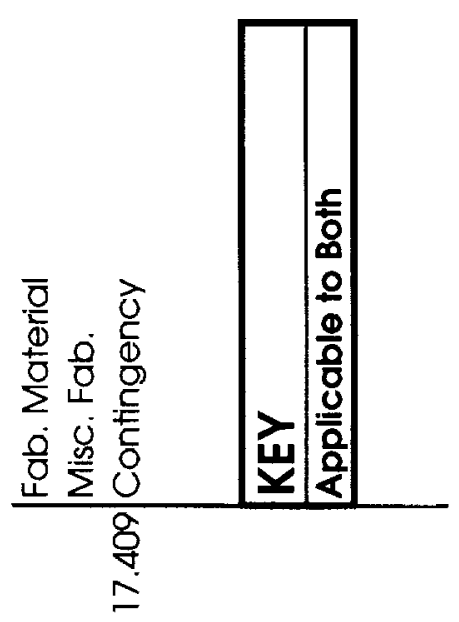

ธิ

$\infty$ 유

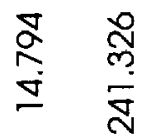

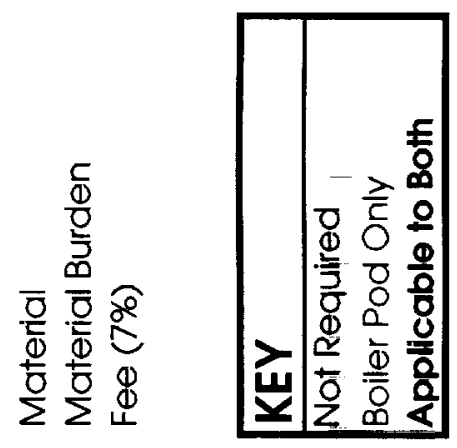

